\title{
Homeostasis, regeneration and tumour formation in the mammalian epidermis
}

\author{
DARIA BELOKHVOSTOVA", IEVA BERZANSKYTE\#, ANA-MARIA CUJBA\#, GERALDINE JOWETT", \\ LUCY MARSHALL\#, JOHANNA PRUELLER ${ }^{\#}$ and FIONA M. WATT** \\ King's College London Centre for Stem Cells and Regenerative Medicine, Guy's Hospital, London, UK.
}

\begin{abstract}
The epidermis is the outer covering of the skin and provides a protective interface between the body and the environment. It is well established that the epidermis is maintained by stem cells that self-renew and generate differentiated cells. In this review, we discuss how recent technological advances, including single cell transcriptomics and in vivo imaging, have provided new insights into the nature and plasticity of the stem cell compartment and the differing roles of stem cells in homeostasis, wound repair and cancer.
\end{abstract}

KEY WORDS: skin, stem cell, plasticity, niche

\section{Introduction}

The skin is one of the largest organs of the human body. It forms a protective interface between the body and the external environment. It is capable of sensing stimuli such as pain and temperature, allowing it to thermoregulate, to form a barrier against water loss, while simultaneously controlling evaporation, and to relay somatosensory information to the brain to inform reflexes and behaviours. To achieve this protection, regulation, and sensation, the skin has evolved as a complex organ capable of interacting with the immune system, muscles, and the brain (Watt 2014).

The outer layer of the skin, the epidermis, is a multi-layered epithelium, known as the interfollicular epidermis (IFE), with associated adnexal structures, comprising hair follicles (HF), sweat glands and sebaceous glands (Fig. 1). Maintenance and repair of the epidermis are dependent on stem cells that both self-renew and give rise to cells that undergo terminal differentiation. Multiple stem cell populations have been identified within mammalian epidermis; these are distinguished by their location and the markers that they express (Schepeler et al., 2014; Goodell et al., 2015).

Below the epidermis lies the dermis, a connective tissue comprising fibroblasts and adipocytes (Fig. 1). The papillary dermis lies closest to the IFE while the reticular dermis consists of the fibroblasts that provide the bulk of collagenous extracellular matrix $(E C M)$ necessary for the structural support of the skin. Beneath the reticular dermis lies the hypodermis, also known as the dermal white adipose tissue. The dermis is highly vascularised and innervated, and cells of the immune system traffic through both the dermis and epidermis (Lynch and Watt 2018).

This review will discuss how recent technical advances, such as live-cell imaging, cell ablation experiments, single-cell analysis, lineage tracing and high-throughput genomics, have offered new insights into the properties of epidermal stem cells and their environment, and how the skin responds to the challenges of wounding and cancer. These studies reveal the skin as a far more heterogeneous and malleable organ than was previously appreciated. In addition, they show parallels with repair and regeneration in model organisms such as zebrafish (Antonio et al., 2015; Richardson et al., 2016).

\section{Epidermal homeostasis}

The epidermis has one of the highest cell turnover rates in the mammalian body, with an average transit time for a cell in the human IFE basal layer to the epidermal surface of just over

\footnotetext{
Abbreviations used in this paper: $\mathrm{BCC}$, basal cell carcinoma; $\mathrm{BMP}$, bone morphogenetic protein; CSC, cancer stem cell; DAMP, damage associated molecular pattern; DETC, dendritic epidermal T cell; Dnmt, DNA methyltransferase; DUX4, double homeobox 4; ECM, extracellular matrix; EMT, epithelial-to-mesenchymal transition; FOXC1, forkhead box C1; HF, hair follicle; IFE, interfollicular epidermis; IL-16, interleukin-16; IL-1 $\beta$, interleukin-1 $\beta$;JMJD3, jumonji-domain containing

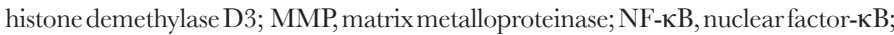
PAMP, pathogen associated molecular pattern; PPAR, peroxisome proliferatoractivated receptor; SCC, squamous cell carcinomas; STAT2, signal transducer and activator of transcription 2; TAC, transit-amplifying cell; TGF $\beta$, transforming growth factor- $\beta$; TNF $\alpha$, tumour necrosis factor- $\alpha$; YAP, yes-associated protein.
}

*Address correspondence to: Fiona M. Watt. King's College London Centre for Stem Cells and Regenerative Medicine, Floor 28, Tower Wing, Guy's Hospital, Great Maze Pond, London SE1 9RT. Tel: +44 (0)20 7188 5608. E-mail: Fiona.watt@kcl.ac.uk - web: www.wattlab.org - (iD) https://orcid.org/0000-0001-9151-5154

\#Note: These authors contributed equally. 


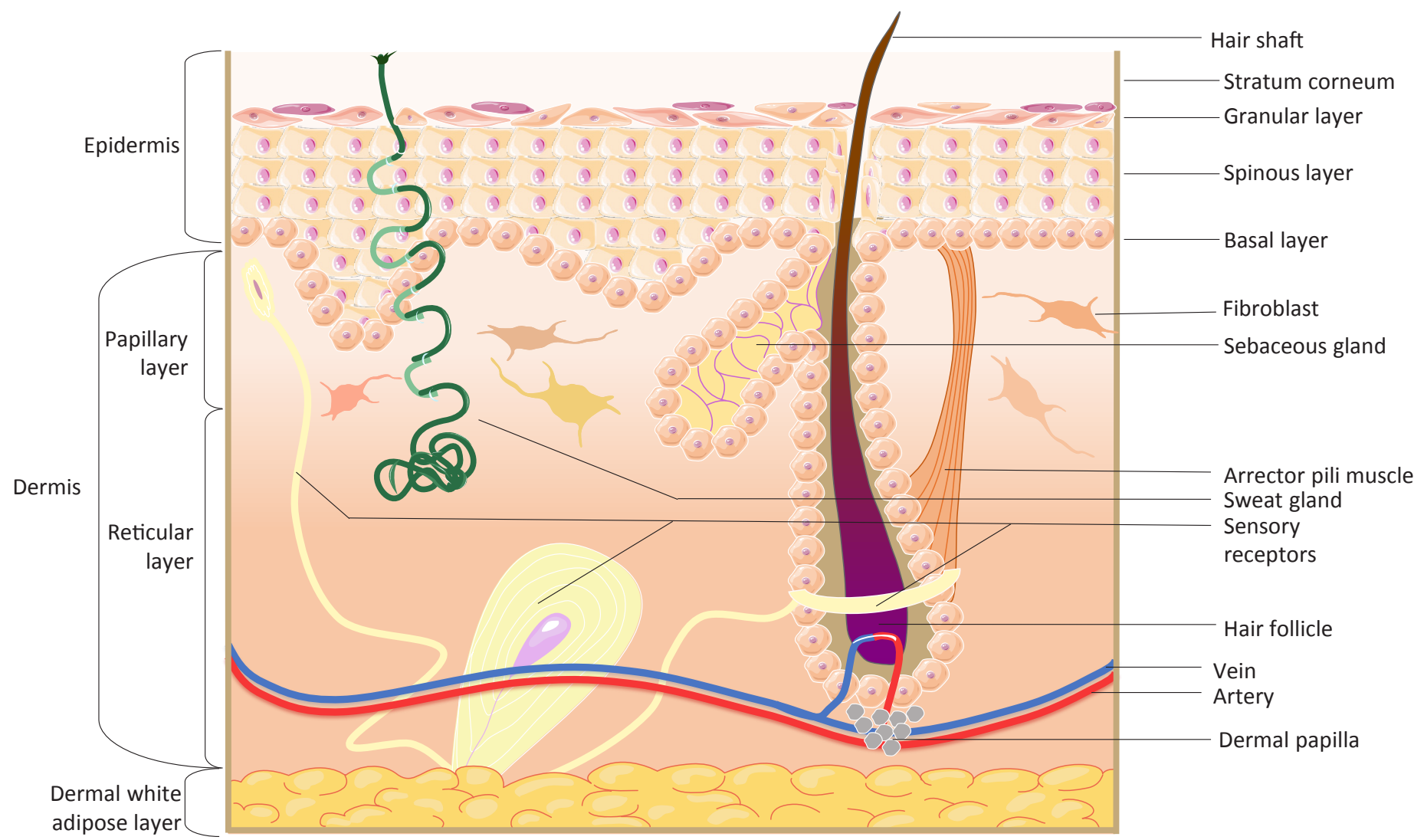

Fig. 1. Schematic representation of human skin. Skin consists of two main layers, the epidermis and dermis. The epidermis between hair follicles is known as the interfollicular epidermis (IFE) which consists of keratinocytes arranged into layers: basal, spinous, granular and stratum corneum. The epidermis also forms adnexal structures, such as hair follicles, sebaceous glands and sweat glands. A basement membrane separates the epidermis from the dermis. The dermis consists of several layers: papillary, reticular and hypodermis/white adipose tissue. The dermis also contains blood vessels, sensory nerves, arrector pili muscles (which control pilo-erection) and dermal papillae, clusters of fibroblasts at the base of hair follicles that regulate the hair growth cycle.

a month (Izuka 1994). Homeostasis is achieved by a balance between cell production via proliferation and cell loss through terminal differentiation. Several different populations of stem cells have been identified in adult mouse epidermis through the use of lineage tracing and flow cytometry (Yang et al., 2017). These include stem cells of the junctional zone between the IFE, $\mathrm{HF}$ and sebaceous gland, which express the receptor tyrosine kinase regulator Lrig1 (Page et al., 2013), and cells of the lower hair follicle that express Lgr5 and CD34. In addition, Gli1+ and Lgr6+ stem cells are found in the upper hair follicle and with the latter scattered within the IFE (Kretzschmar et al., 2016) (Fig. 4A). Lgr5 and Lgr6 are R-spondin receptors and thus participate in Wnt signalling.

Until recently, the focus was primarily on stem cell subtypes within the HF, but now there is an increasing interest in IFE stem cells. Early studies of mouse epidermis revealed heterogeneity in the propensity of basal IFE cells to proliferate, and the concept arose that stem cells renew infrequently, while their progeny undergo a small number of amplifying divisions prior to the onset of terminal differentiation (Jones et al., 2007). Such so-called transit amplifying cells were also identified in studies of colony formation by cultured human epidermal cells. However, lineage tracing studies of the progeny of Lrig1+, Lgr5+ and Lgr6+ stem cells indicate that various stem cell populations differ in their proliferative frequency under steady state conditions, both in the IFE and HF (Kretzschmar et al., 2016). In addition, in vivo clonal analysis of mouse IFE stem cells showed that clone size could be explained by a single population of cells that proliferated or differentiated through a stochastic process (Clayton et al., 2007).

The epidermis of the mouse tail lends itself to clonal analysis because of the highly patterned arrangement of HFs, and the ease with which sheets of epidermis can be prepared for wholemount labelling (Braun et al., 2003). Although clonal dynamics of tail IFE can be explained by neutral drift of a single cell population (Clayton et al., 2007), it has recently emerged that there are two types of differentiated epidermis, scale and interscale, each of which is maintained by a distinct stem cell population (Gomez et al., 2013). Recently, Sada et al., used lineage tracing in Slc1a3 ${ }^{\mathrm{CreER}}$ and DIX1 ${ }^{\mathrm{CreER}}$ mice to show that IFE stem cells are present as fast and slow dividing populations with distinct patterns of differentiation kinetics (Sada et al., 2016). Interestingly, both of these populations contribute to long-term regeneration, challenging the classic 'quiescent versus active stem cell' theory (Adam et al., 2015), and the hypothesis that there is a hierarchy of stem cells and committed progenitors within the IFE basal layer (Mascré et al., 2012). Single-cell transcriptomic analysis of cultured human epidermal cells (Tan et al., 2013) and mouse epidermis (Joost et al., 2016) support the concept of IFE stem 
cell heterogeneity. Both of the studies found at least two distinct transcriptional signatures in IFE stem cells and potential novel markers and regulators, such as CD46 and DIl1 in human and THBS1 and BHLHE1 in mouse.

\section{Intrinsic and extrinsic regulators of the epidermal stem cell niche}

The behaviour of epidermal stem cells is dependent on complex interactions between stem cells and other cellular components of the skin, and is controlled by secreted factors, ECM, physical parameters, immunological and metabolic factors. Together, these individual components of the stem cell microenvironment constitute the niche. Thus the niche comprises a number of external factors involved in the maintenance of epidermal stem cells in a tissue context-dependent manner (Lane et al., 2014). The signalling pathways classically associated with epidermal stem cell maintenance and differentiation include the mitogenactivated protein kinase (MAPK) pathway (Jung et al., 2016), as well as Wnt (Lim et al., 2013; Augustin 2015), and Notch signalling (Okuyama et al., 2008). These major pathways, along with multiple more recently identified regulators, are controlled by external signals provided by the ECM, secreted molecules and contact with neighboring cells.
The ECM maintains epidermal homeostasis via components of the epidermal basement membrane such as collagen VII, which is the major component of anchoring fibrils (Martins et al., 2016). Both epidermal and dermal cells synthesise basement membrane proteins. Integrin ECM receptors are expressed by the epidermal stem cell compartment (Arwert et al., 2010) and mediate both adhesion and suppression of differentiation. Pathways that regulate epidermal homeostasis via secreted molecules include those mediated by peroxisome proliferator-activated receptors (PPAR) and transforming growth factor $\beta$ (TGF $\beta$ ) receptors (Schmuth et al., 2014). Bone morphogenetic protein 4 (BMP4) signalling is particularly important in controlling HF stem cell homeostasis (Genander et al., 2014). BMP signal-transduction occurs via SMAD proteins, but in HF stem cells SMAD2 is also regulated by SOX9, a transcription factor that is necessary for HF stem cell proliferation (Kadaja et al., 2014). Additionally, Lay and colleagues have shown that the transcriptional regulator Forkhead box C1 (FOXC1), which is a downstream target of BMP-SMAD1 signalling, plays a major role in regulating stem cell activity in HFs and thus the hair growth cycle (Lay et al., 2016).

Extrinsic factors that affect cell fate are not limited to ECM molecules and secreted ligands. The influence of niche cells on epidermal stem cells has recently become evident. As one example, adipocytes in the lower dermis provide signals including BMP4 and

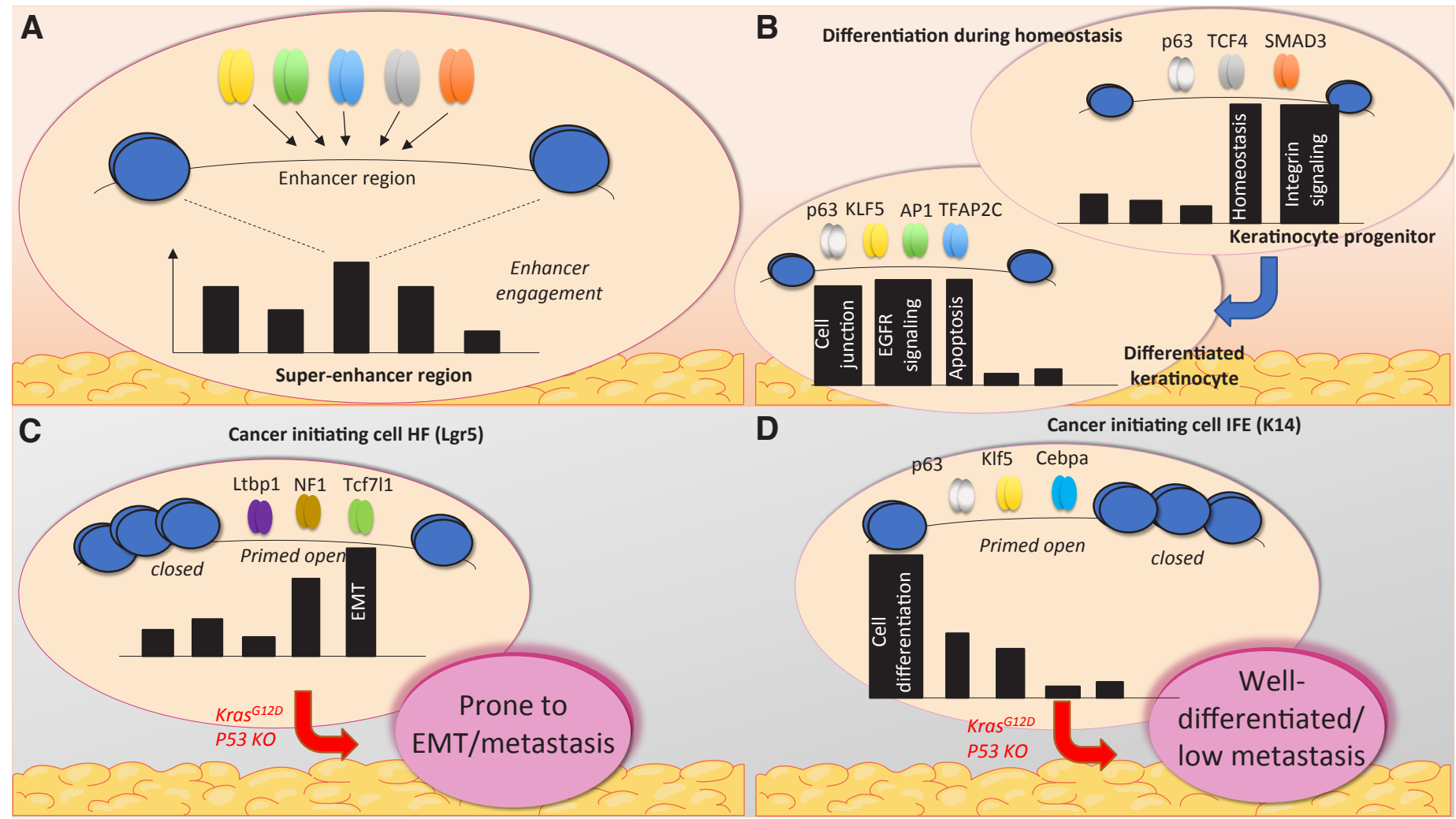

Fig. 2. Switch in super-enhancer usage in different cellular states. Super-enhancers are extensive regions within the genome containing multiple TF-recruiting sequences, i.e. enhancers. (A) Super-enhancer usage changes during differentiation of keratinocytes. Recruitment of control regions, involved in homeostasis and integrin signalling, is reduced, and replaced by areas responsible for genes involved in cell-cell junctions, apoptosis and EGFR signalling. (B) Enhancer recruitment differs in various types of cells, such as HF or IFE cells. In tumours, these enhancers determine the properties of the tumour by engagement of different genes. For example, if the cancer-originating cell is of HF origin, genes that are primed open will more likely cause metastasis (C). On the contrary, IFE cells contain enhancers primed towards cell differentiation, and hence tumours are better differentiated and rarely metastasise (D). 
EGF to HF stem cells, regulating their activation and therefore hair growth (Schmidt and Horsley 2012). Regulation of the HF cycle by direct interaction of Tregs and HF stem cells in a Notch-dependent manner (Ali et al., 2017) and effects of macrophages on HF stem cells in a Wnt-dependent manner (Castellana et al., 2014; Chen et al., 2015) provide important insights into immune regulation of epidermal stem cells.

Epidermal homeostasis is also controlled by complex endogenous mechanisms. The terminal differentiation of keratinocytes is accompanied by dynamic changes in nuclear morphology, creating distinct patterns that correlate both with cell fate and cell cycle stage (Karasek et al., 1972). These morphological phenotypes have been associated with the redistribution of active chromatin territories and nucleolus positioning, thus regulating gene activation and silencing (Gdula et al., 2013). As cells undergo terminal differentiation the number of heterochromatin clusters increases. This relates transcriptional gene silencing to transitions in the nuclear architecture of differentiating keratinocytes.

Cell-specific transcriptional changes are also controlled by genomic regions that contain multiple regulatory regions called super-enhancers (Yang et al., 2015). These super-enhancers are capable of dynamically recruiting numerous sets of transcription factors (Fig. 2A). As stem cells differentiate, the use of enhancer regions shifts, with more than half of active super-enhancer regions unique to the stage of keratinocyte differentiation (Adam et al., 2015). For example, transcription factors acting on super-enhancer regions in keratinocyte progenitors relate to homeostasis and integrin signaling, whereas in more differentiated keratinocytes the transcription shifts to cell-junction and apoptosis-related genes (Fig. 2B) (Cavazza et al., 2016).

Other epigenetic changes that are associated with epidermal homeostasis include targeted histone modifications. Histone modifications can open up the chromatin or create specific binding sites for chromatin modifying proteins. These modifications can occur at very specific gene loci. For instance, differentiating keratinocytes lose repressive histone 3 lysine 9 trimethylation (H3K9me3) selectively at Double Homeobox 4 (Dux4) and Dux4-like genes, which upregulates the expression of this transcription factor (Gannon et al., 2016). Other mechanisms control a more global change in gene expression. DNA methyltransferase 1 (Dnmt1) is required for the maintenance of basal epidermal stem cell multipotency, while Dnmt3a and Dnmt3b bind to active enhancer regions via the p63 master regulator to control the levels of DNA methylation and/or hydroxymethylation of active enhancers (Rinaldi et al., 2016). This enzymatic regulation of epigenetics affects downstream gene expression, most of which is involved in self-renewal and interaction with the niche. While recent in vivo studies suggest that Dnmt3a and Dnmt3b are not essential for epidermal homeostasis, the loss of Dnmt 1 results in differentiation of epidermal stem cells, and loss of Dnmt3a results in the formation of epidermal squamous tumours (Rinaldi et al., 2016).

\section{Wound healing: inflammation, re-epithelialization and tissue remodelling}

As the skin is the outermost protective organ of the body, it is highly susceptible to wounding and tissue damage. On wounding, epidermal homeostasis is disrupted; the repair process involves re-establishment of homeostasis. The wound healing process is divided into three main stages: inflammation, re-epithelialization, and epidermal remodelling (Landén et al., 2016). During the inflammatory phase of wound healing, a blood clot forms and innate immune cells, including macrophages and neutrophils, are mobilised. The re-epithelialization process involves the formation of new connective tissue, the reconnection and reopening of blood- vessels, and the replenishment of squamous epidermal cells. Finally, the dermis and epidermis are remodelled to regain their original architecture (Sun et al., 2014). The tissue returns to normal following superficial injuries, but repair is accompanied by scarring following healing of deeper wounds (Eming et al., 2014). In a wound context, stem cells from the HF, IFE, and infundibulum all contribute to epidermal regeneration (Arwert et al., 2012).

Immediately after injury, haemostasis and platelet aggregation control bleeding from damaged vessels. The resulting activation of the blood coagulation cascade results in fibrin clot formation, which not only stops the bleeding, but also acts as a scaffold for cell attachment at a later stage (Xue and Jackson 2015). Next, resident skin cells near the injury site, such as keratinocytes, macrophages, and dendritic cells, become exposed to a variety of danger signals. Host cells undergo necrosis as a result of injury, causing them to release damage associated molecular patterns (DAMPs) in the form of DNA and RNA (Fig. 3). Due to the barrier rupture, pathogen associated molecular patterns (PAMPs) associated with microorganisms from the skin microbiome, as well as invading pathogenic organisms, will reach resident cells (Strbo et al., 2014). These DAMPs and PAMPs are picked up by receptors, and trigger the activation of both adaptive and innate immune responses. This immune signalling cascade can be broadly divided into an early and a late stage. The early phase involves neutrophil recruitment and prevention of infection, whilst the late phase involves infiltration and maturation of monocytes.

Neutrophils play an essential role in epidermal injury. As well as inducing phagocytosis of invading microorganisms and host necrotic tissue, they secrete cytokines including tumour necrosis factor- $\alpha$ (TNF $\alpha$ ), interleukin-1 $\beta$ (IL-1 $\beta$ ) and interleukin-16 (IL-16) to act as chemoattractants for additional inflammatory cells, thus amplifying the immune response (Eming et al., 2014). Approximately three days after the injury is sustained, monocytes reach the wound (Reinke and Sorg 2012), where they mature into a spectrum of macrophage phenotypes (broadly characterised as pro-inflammatory M1 and pro-repair M2 macrophages) to support the neutrophils in phagocytosis and chemokine secretion, resulting in inflammation (Martinez and Gordon 2014). Unlike neutrophils, which are only present for the initial wound healing response, macrophages will persist at the wound site throughout all stages of repair (Eming et al., 2007). At each stage, macrophages play different roles, including the induction of granulation tissue in the early stage and stabilising vascular structures in the mid-stage (Lucas et al., 2010). Macrophages present in the granulation tissue in the mid-stage are crucial for progressing repair into the final stages of tissue maturation, whereas macrophages present during the late stage play a less vital role (Lucas et al., 2010).

After this early innate response, a specific adaptive immune response is carried out by antibody producing B-cells and cytokine secreting T-cells. In the skin there is a particular subpopulation of antimicrobial T-cells that carry a $\mathrm{T}$ cell receptor composed of $\kappa$ and $\delta$ subunits, known as dendritic epidermal T cells (DETCs) similar to dendritic cells that monitor keratinocytes for damage. 
After injury, DETCs retract their dendrites to allow proliferation and migration of both keratinocytes and neighbouring DETCs, a key process in wound healing (Strbo et al., 2014). The importance of DETCs in the wound healing process was demonstrated by deletion of IL-17A+DETCs, which resulted in delayed wound closure (MacLeod et al., 2013).

Following inflammation, epidermal cells proliferate and migrate to re-epithelialise the wound. Recent work has identified the dynamics of two epidermal compartments which are differentially regulated during re-epithelialisation of mouse tail epidermis: a proliferative compartment containing HF, IFE-derived progenitors and stem cells, and a migratory leading edge composed of non-proliferating cells (Fig. 4B; Aragona et al., 2017). Initially, progenitor populations differentiate rapidly, and are therefore rapidly depleted. In response to this depletion quiescent stem cells become activated and begin replenishing the stem cell pool by generating new progenitor cells, which in turn promote tissue expansion. While this proliferation promotes tissue re-growth, the second compartment containing migratory non-proliferating cells provides the scaffold for ECM, remodelling the connective tissue to progress toward the wound centre (Aragona et al., 2017). In vivo imaging in injured mice has elucidated how the two epidermal compartments contribute to wound healing with minimal disruption to homeostasis (Park et al., 2016). Proliferative cells migrate and proliferate in the direction of the wound to allow epidermal stratification, and the rates of this stratification are determined by wound proximity, with areas nearest the wound being differentially regulated compared to normal reepithelialization, a difference that can lead to scar tissue formation (Park et al., 2016).

The final stages of wound healing involve fibroblast proliferation and ECM remodelling. Different fibroblast lineages play different roles during wound healing. The upper dermal lineage is required for HF neogenesis, while the lower dermal lineage contributes pre-adipocytes and adipocytes, and cells that secrete fibrillar ECM (Driskell et al., 2013). During repair, fibroblasts in the lower dermis are mobilised first, followed by recruitment of upper dermal fibroblasts. Expansion of both fibroblast lineages can be activated by the canonical Wnt pathway, and in the upper dermis Wnt signalling promotes the formation of new HFs (Driskell et al., 2013). The failure of postnatal wounds to regenerate hair follicles within the

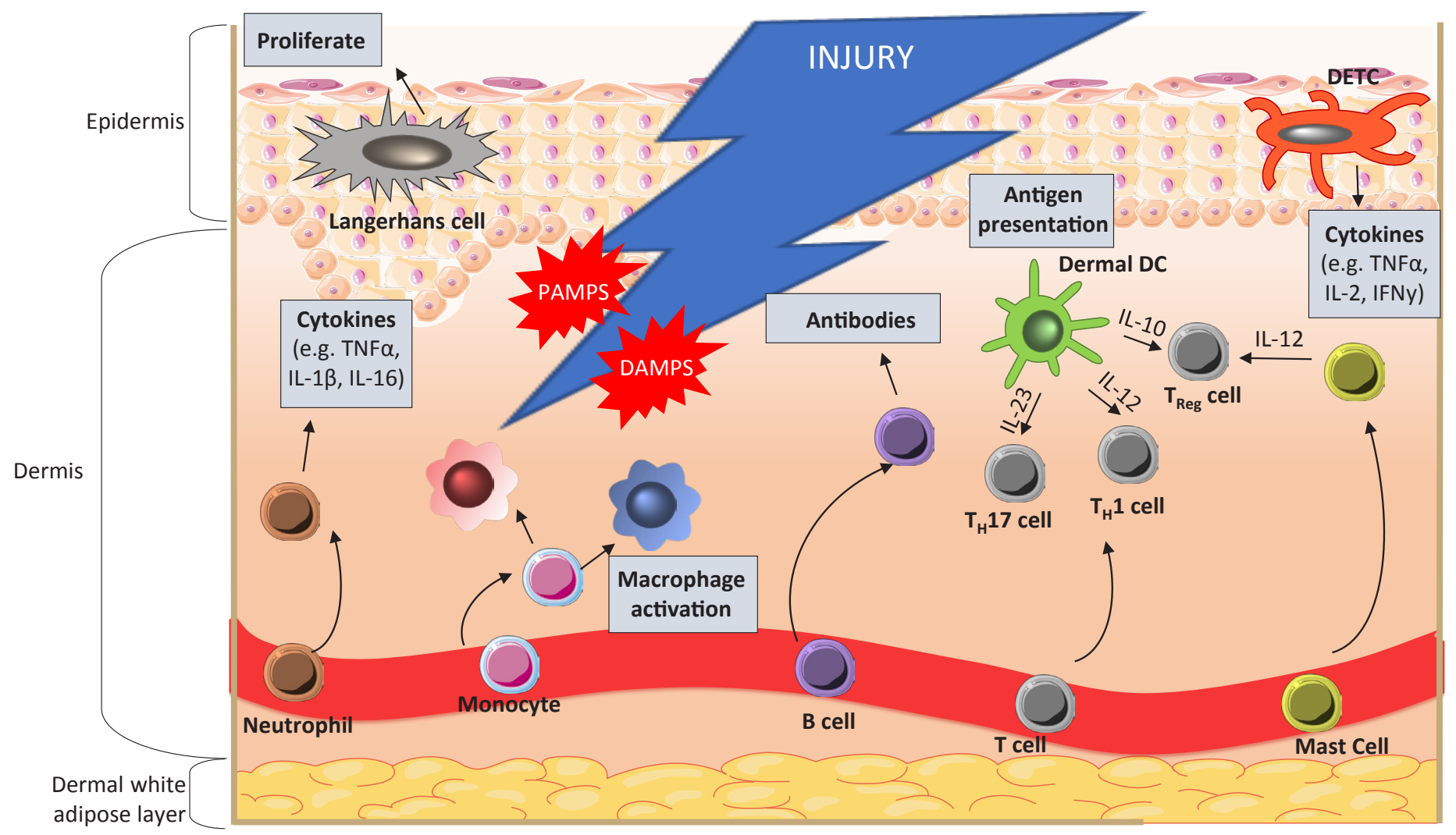

Fig. 3. Inflammatory response to injury. During injury, resident skin cells, including keratinocytes, macrophages, and dendritic cells, are exposed to danger signals from host cells, DAMPs (damage associated molecular patterns), invading microorganisms and PAMPs (pathogen associated molecular patterns). Neutrophil invasion is required initially for phagocytosis and cytokine secretion, to amplify the immune response. Infiltration and maturation of monocytes into a spectrum of macrophage phenotypes occurs to support inflammation. Dermal dendritic cells (DCs) aid in T cell polarisation to TH1, $T_{H} 17$ and Treg through presentation of antigens and release of cytokines. Langerhans cells are involved in immune surveillance and are the first-line of defence in epidermal wounds. Upon inflammation, cells become activated and promote re-epithelialisation through induction of keratinocyte proliferation and differentiation. DETCs are the only resident T cells in mouse epidermis and are crucial for immune surveillance and homeostasis. Signals from damaged keratinocytes activate DETCs, which regulate further immune responses. Mast cells and dermal DCs establish the balance between pro- and anti-inflammatory responses through secretion of specific cytokines. An adaptive immune response occurs after the initial inflammation, and involves $B$ and T cells. B cells produce antibodies against invading pathogens whilst T cells secrete cytokines and growth factors. 
wound bed is linked to loss of the papillary fibroblasts and altered dermal Wnt signalling (Rognoni et al., 2016).

ECM remodeling following wound closure can take several months and involves many components. Collagens, elastins, fibronectins and laminins provide flexibility whilst proteoglycans and hyaluronans interact with integrins to regulate cell signaling and adhesion between the ECM and surrounding cells (Xue and Jackson 2015). Restoration of a functional epidermal barrier after a superficial injury is normally highly efficient; however damage to deep dermal layers is not, and this is when scarring occurs (Eming et al., 2014). When scar formation occurs, the wound is considered to be repaired, whereas regeneration refers to full recreation of the original tissue. During normal wound healing, keratinocytes express laminin that binds preferentially to a3 $\beta 1$ integrin, an interaction that promotes wound healing by stabilising the epidermal basement membrane. However, a lack of a $3 \beta 1$ integrin induces a rupture of the basement membrane beneath the epidermis of the wound (Longmate et al., 2014). This is characterised by extensive blistering, illustrating how dysregulated ECM remodeling can prevent resolution of wound healing. Interestingly, micro-RNAs are thought to regulate ECM remodeling during wound healing. For example, miR-378 upregulates integrin $\beta 3$ and vimentin, whilst miR-29 is involved in the synthesis of ECM protein collagens ( $\mathrm{Li}$ et al., 2014; Ti et al., 2014).

\section{Injury-associated epidermal cell plasticity}

In response to injury, stem cells in a range of tissues exhibit plasticity - by switching from one stem cell type to another or by generating a wider range of differentiated lineages than under steady state conditions (Rajagopal and Stanger 2016). This type of stem cell plasticity is observed during epidermal wound healing (Blanpain and Fuchs 2014; Donati and Watt 2015). Genetic lineage tracing and intravital microscopy in mice showed that it is the location of cells in the HF niche that directs their fate towards remaining as uncommitted stem cells, switching towards hair-germ progenitor fate, or terminally differentiating to contribute to the regenerated tissue (Fig. 4C; Rompolas et al., 2013). When HF stem cells are removed by laser ablation, neighboring epithelial cells with distinct functions replace them, suggesting a potent role for extracellular niche factors in inducing cell plasticity (Rompolas et al., 2013).

A recent study of epidermal wound healing has demonstrated that terminally differentiated Gata6 ${ }^{+}$sebaceous duct cells can migrate into the IFE, where they dedifferentiate into self- renewing stem cells capable of giving rise to multiple epidermal lineages (Donati et al., 2017) (Fig. 4D). Analysis of genetically-labelled Gata6 ${ }^{+}$cells and Lrig $1^{+}$stem cells using live imaging, transcriptomics, histology, and skin reconstitution assays reveals that both cell types exhibit stem cell characteristics after wounding. However, Gata6 ${ }^{+}$cells show an improved multi-lineage differentiation capacity, which could be attributed to Gata6 acting as a pioneer transcription factor that regulates genes involved in cell motility during the wound repair process. The study showed that both cell types contribute to the wound- healing process: Lrig1 ${ }^{+}$stem cells enter the wound together, whereas the Gata6 ${ }^{+}$cells migrate independently in the suprabasal layer and dedifferentiate into stem cells close to the wound (Donati et al., 2017).

One potential mechanism underlying this plasticity lies with epigenetic super-enhancers (Adam et al., 2015). The binding epicenters of these super-enhancers appear to shift upon injury in HF stem cells, which both inhibits the binding of HF stem cell transcription factors and enhances the binding of wound-repairrelated transcription factors, thus enabling the transitional plasticity of HF stem cells during healing. The activation of super-enhancers is determined by SOX9, which here may act as a microenvironment sensor, regulating chromatin changes to determine cell fate, identity, and plasticity of the epidermal stem cell niche (Adam et al., 2015).

Much like Gata6 ${ }^{+}$sebaceous duct cells and HF cells, terminally differentiated keratinocytes are also capable of proliferation and migration in response to injury. The particular contribution of these cells is also determined by their location relative to the wound, and this location-dependent specification appears to rely on epigenetic mechanisms. For example, miR-203 is a key regulatory skin miRNA involved in stem cell differentiation (Yi et al., 2008), and it is differentially expressed in keratinocytes depending on their location with respect to the wound (Viticchiè et al., 2012). Highly proliferative and migratory wound- adjacent keratinocytes show downregulated expression of miR-203, whereas cells distant from the wound have higher expression of miR-203 and undergo differentiation. During re- epithelialization, gene expression changes are also affected by other epigenetic mechanisms, such as histone modifications by Jumonji-domain containing histone demethylase D3 (JMJD3), which is capable of reversing the repressive mark of histone 3 lysine 27 trimethylation (H3K27me3) (Xiang et al., 2007). JMJD3 is upregulated in wound-proximal keratinocytes, where it also interacts with the Nuclear Factor-kB (NF-kB) inflammatory signaling pathway ( $\mathrm{Na}$ et al., 2016). Consistent with the downregulation of miR-203 at the wound edge, JMJD3 is also involved in epigenetic suppression of differentiation (Chen et al., 2016). Similarly, histone methyltransferase Ash1l is involved in the control of re- epithelialization. Ash1l mutant mice show delayed re-epithelialization and have increased keratinocyte proliferation at the wound edge ( $\mathrm{Li}$ et al., 2017a). Together these elegant lineage tracing and chromatin studies suggest a strong role for epigenetic mechanisms in injury- induced plasticity of skin cells.

\section{Epidermal stem cells and cancer}

There is a fine balance between wound healing and tumorigenesis, as similar cell types and signaling pathways contribute to both processes. However, while wound healing is inherently a self-limiting process, tumour formation is characterized by the constitutive or aberrant activation of stem cell and regeneration associated pathways like Wnt signaling. Tumours of the epidermis, basal cell carcinomas (BCCs) and squamous cell carcinomas (SCCs), are the most common types of cancer in humans, and both can develop in response to wounding (Arwert et al., 2012).

By genetically targeting oncogenes to different epidermal compartments in the mouse, it has been established that the response to a given oncogenic change depends on the cell that is targeted. For example, expression of mutant oncogene Ras in the differentiated cell layers results in benign lesions, while targeting it to the basal layer, where the stem cells are located, leads to malignant lesions (reviewed by Owens and Watt 2003). Ectopic activation of $\beta$ - catenin similarly results in different types of epidermal tumour formation, depending on whether the Lrig1, Lgr5 or Lgr6 ${ }^{+}$stem cell populations are targeted (Kretzschmar et al., 2016). It remains to be resolved whether the different outcomes are determined by 
the intrinsic nature of the stem cells or by their different niches. However, recent studies involving intra-vital imaging of mouse epidermis have shown a positive role of genetically wild-type cells in eliminating cells in which the Wnt pathway is abnormally activated (Brown et al., 2017).

The term 'cancer stem cell' (CSC) often refers to a cell that has tumour-propagating properties in transplantation experiments.
The transient plasticity of skin stem cells during wound healing contributes to repair; however, a link between regeneration and higher susceptibility towards cancer has been established both in mouse models (Guasch et al., 2007) and on the molecular level (Chang et al., 2004). A recent study explored this connection by looking at different enhancer engagement and transcriptional states of cancer stem cells compared to wound-induced HF stem cells
B
A

Homeostasis

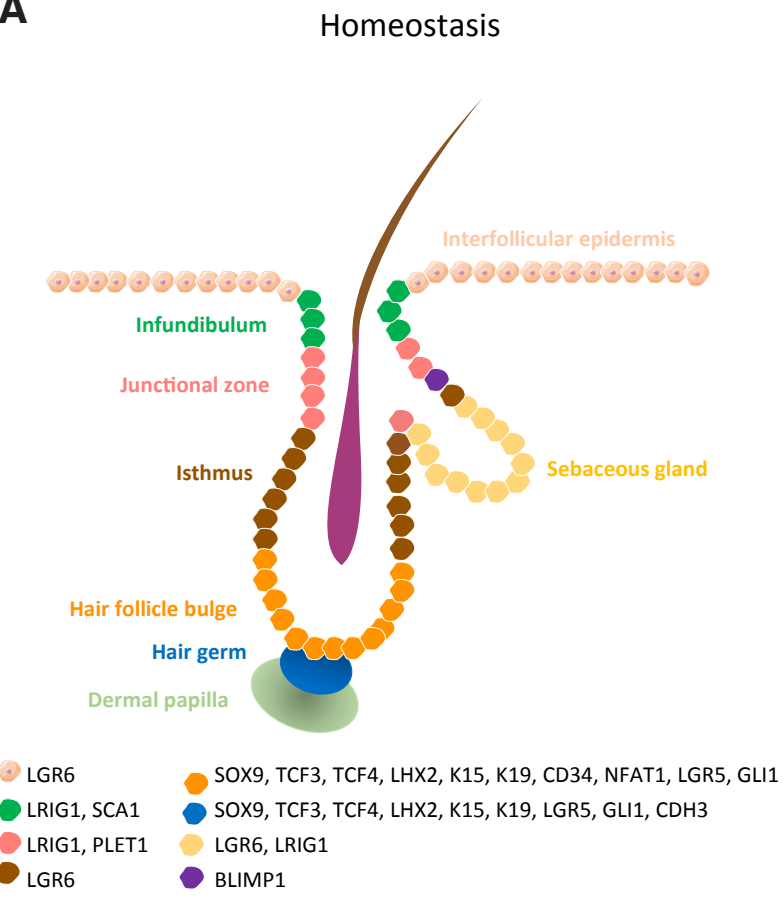

C Re-epithelialization: stem cell interchange

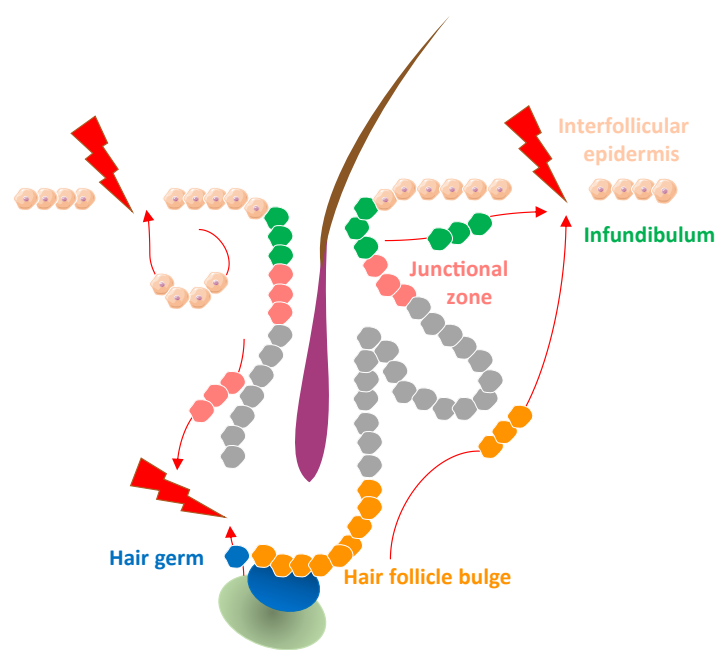

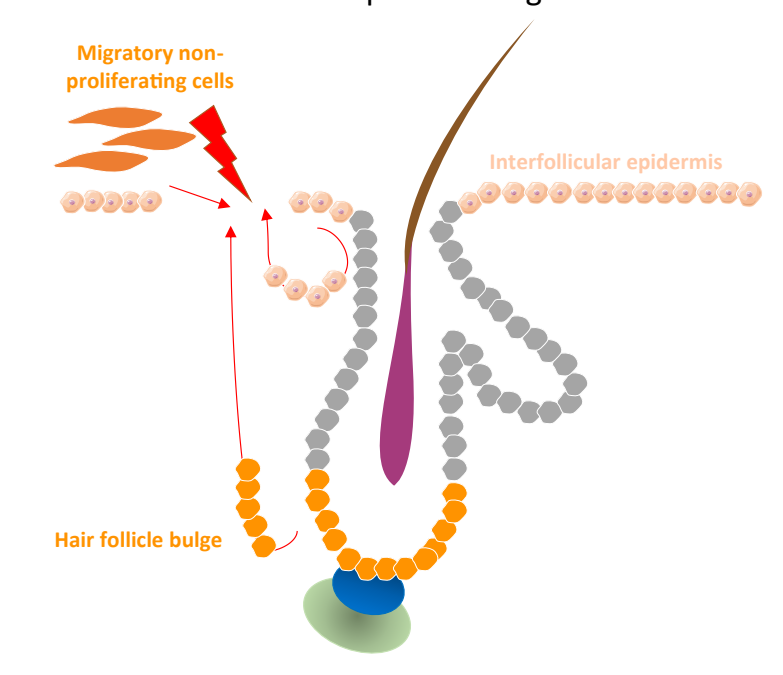

\section{differentiated cells}

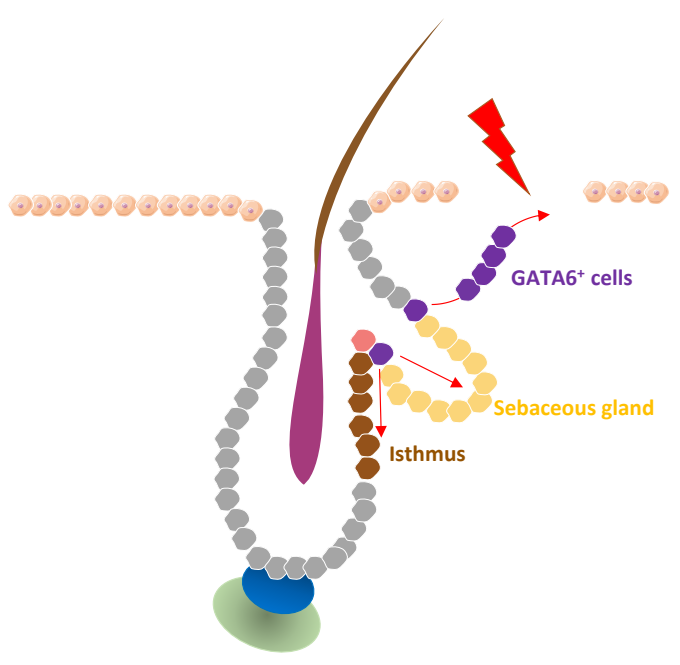

Fig. 4. Mechanisms of re-epithelialization. Epidermal stem cell compartments that maintain skin homeostasis and their associated markers (A). Re-epithelialization upon injury occurs via several paths: contribution of the proliferative hub (IFE hair- follicle stem cells and their progeny) and nonproliferative migratory cells (at the leading edge) to the initial stages of re-epithelialization (B). When stem cell compartments from the IFE, infundibulum, junctional zone and hair follicle bulge and germ exhibit plasticity, they contribute to the replenishment of stem cells lost on wounding (C). Terminally differentiated cells such as GATA6+ cells de-differentiate and contribute to re-epithelialization of damaged IFE and re-populate the sebaceous gland and lower hair follicle during wound healing (D). 
and epidermal stem cells (Ge et al., 2017). Deletion of SOX9 and KIf5 indicated that these transcription factors contribute to both wound repair and cancer. During healing, these transcription factors interact with low-stress enhancers that mark transient lineage infidelity to resolve tissue damage, whereas in cancer, specific tumour-associated high-stress enhancers induce permanent lineage infidelity.

One phenomenon that has been explored in the context of epidermal tumours is epithelial-to- mesenchymal transition (EMT; reviewed by Canel et al., 2013). In one experimental model, IFEderived cancer cells retain epithelial characteristics, whereas HF-derived cancer cells appear more prone to undergo EMT (Fig. 5). Transplantation of cancer cells derived from these two cell lineages, followed by chromatin and transcriptional profile analysis, revealed that it is the intrinsic epigenetic and transcriptional state that controls SCC fate (Latil et al., 2017). Transcription factors such as p63, Klf5, and $\mathrm{C} / \mathrm{epb} \alpha$ prime IFE stem cells to become fully differentiated SCC, whereas transcription factors Tcf7l1 and Tbx1 prime HF stem cells to develop EMT-based SCC. Therefore, the chromatin states allow interaction with tumour-specific factors to induce different SCCs.

Shifts in super-enhancer regions occur during wound-induced plasticity, but also in tumour-initiating cells, potentially as a result of the altered cellular microenvironment (Oshimori et al., 2015). For example, super-enhancer regions that appear active in the cells that initiate SCCs are very different from those in normal HF stem cells, associating with known oncogenes, such as Myc and SCCspecific Cd44 (Yang et al., 2015). It has been shown that tumour profile may depend on epigenetic modifications in the originating cells type (Latil et al., 2017). For example, SCC caused by the same oncogenic mutations in HF originating cells exhibit EMT more frequently (Fig. 2C) compared to SCC originating from IFE stem cells (Fig. 2D) and differ in their metastatic potential. Due to the different chromatin states in these two types of cell, the accessibility to EMT genes varies and correlates with the ability to undergo EMT.

\section{Deregulation of signalling pathways in skin cancer}

EMT conversion in cancer is triggered by multiple signalling pathways, most notably TGF $\beta$ and canonical Wnt signalling. Loss of epithelial E-cadherin not only promotes migration and metastasis by reducing intra-epithelial junctions, but it releases the Wnt-mediator $\beta$-catenin into the cytoplasm, allowing this protein to translocate into the nucleus, a state that is highly correlated with BCC development in mice (Pantazi et al., 2017). Another abnormal activation commonly found in BCC is that of $\mathrm{TGF} \beta$, which causes overexpression of transcription factor SNAIL, associated with EMT

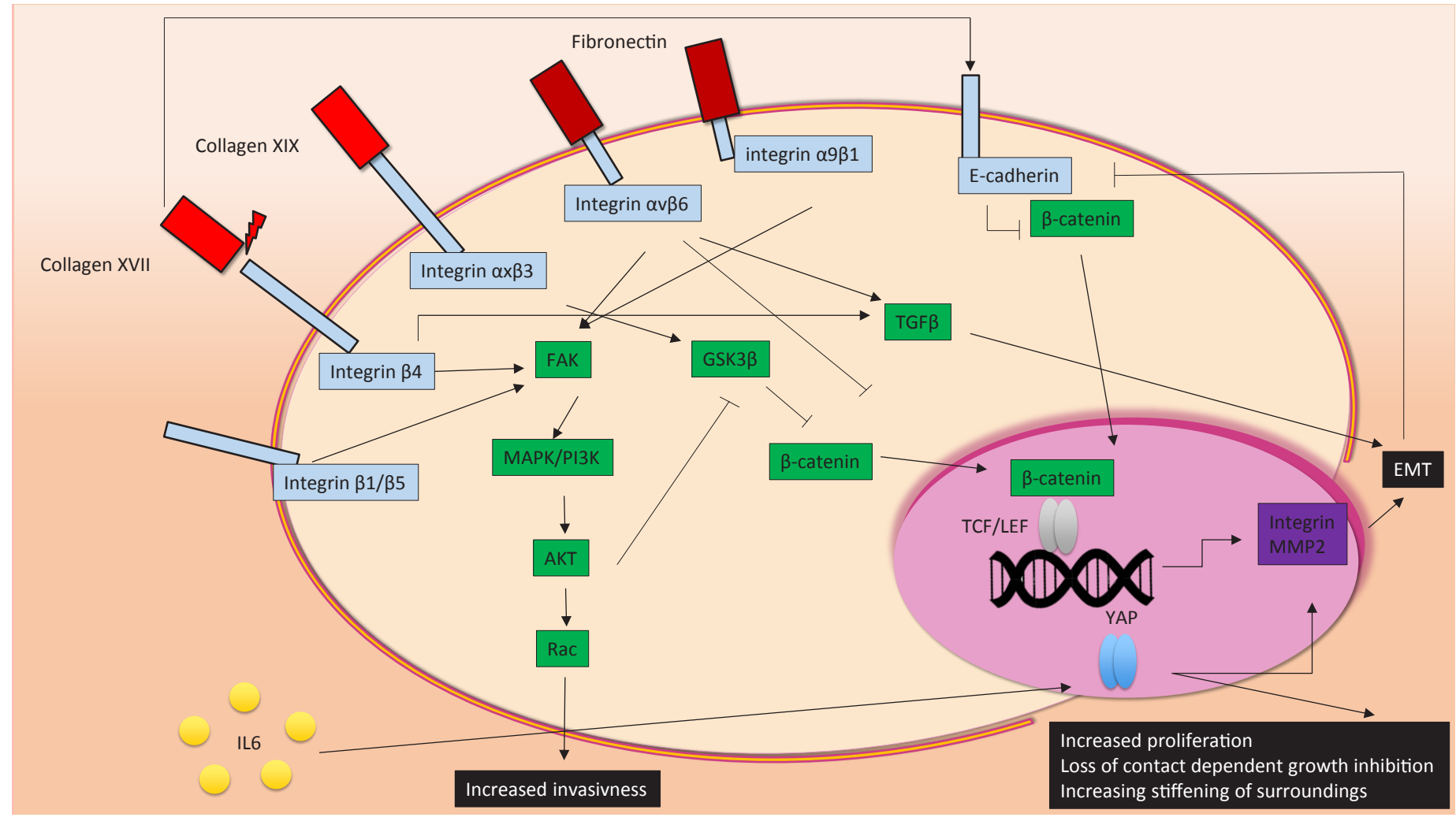

Fig. 5. Deregulated signalling influences skin cancer progression. Components of the extracellular matrix (ECM), such as collagens and fibronectin, interact with cell surface integrins and cadherins. Depending on which surface molecule they interact with, the cancer hallmarks (uncontrolled proliferation, invasiveness and epithelial-to-mesenchymal transition (EMT)) can either be activated or repressed. Activation of the MAPK/PI3K pathway, mediated by integrin stimulation, facilitates nuclear translocation of $\beta$-catenin, resulting in EMT and increased invasiveness. EMT is also induced by TGFß signalling, through collagen- and fibronectin-integrin associations. Other stimuli, including secreted cytokines, can contribute to cell transformation. For example, YAP signalling is activated by IL-5, in turn causing increased proliferation and loss of contact-dependent growth inhibition, which is typical behaviour associated with cancer cells. 
(De Craene et al., 2014).

EMT can also be caused by transcriptional upregulation of integrins and ECM-degrading matrix metalloproteinases (MMP) (Luo et al., 2016). MMPs degrade the surroundings of mesenchymal cells to allow them to migrate within the body, which also affects the mechanical properties of the surrounding matrix. These changes are processed by nuclear mechanosensing Yes-associated protein (YAP) of the HIPPO signalling pathway (Gregorieff et al., 2015; Hong et al., 2016). Activation of the Src/EGFR/MAPK/PI3K pathway in response to matrix property changes allows transcription factor YAP to enter the nucleus, promoting transcription of genes that are associated with cell growth, cell cycle progression, and cell-matrix interaction (Elbediwy et al., 2016). Additionally, YAP activation is altered in response to the mechanically stiffer environment of fibrotic and tumorous tissue. YAP- localisation to the nucleus is also elevated in the presence of IL-6, which is present during wound healing and inflammation (Taniguchi et al., 2015).

Integrins play an essential role in the regulation of MAPK/PI3K, Wnt, and Yap/Taz pathways (Huang et al., 2011). Integrin $\beta 1$ is particularly important for the expression of matrix remodeling and invasion genes. In skin cancer, interference with integrin $\beta 1$ activity can have markedly different outcomes, from increased invasiveness and migration to a complete loss of invasive phenotype. Interference with integrin $\beta 1$ clustering by TSPAN8 or FRA1 causes impaired phosphorylation of AKT, manifesting itself in enhanced invasiveness and migration (El Kharbili et al., 2017; Zhang et al., 2016). Integrin $\alpha v$ on the other hand controls the expression of oncogene c-Myc, through Focal-Adhesion Kinase dependent activation of p38 and p90RSK pathways (Srivastava et al., 2016). When integrin $\alpha \mathrm{V}$ heterodimerizes with either integrin $\beta 5$ or $\beta 6$, it becomes essential for de novo tissue generation and neoplastic invasion (Duperret et al., 2015). Integrin $\alpha \mathrm{v} \beta 6$ controls TGF $\beta$ activation, and inhibits $\beta$-catenin signalling, thereby regulating EMT (Rognoni et al., 2014).

While stiffness and adhesion mediating proteins are important components of EMT and metastasis, the actual makeup of the ECM also plays a crucial role in balancing wound healing and carcinogenesis. Collagen XVII is essential for cell adhesion and migration, and the interaction between collagen XVII and integrin $\beta 4$ can cause cells to acquire a non- directional, invasive, and migratory phenotype (Tasanen et al., 2004). Collagen XVII is upregulated during re-epithelialisation of wounds, as well as at the invasive front of SCC (Löffek et al., 2014). Additionally, knockdown of either collagen XVII, integrin $\beta 4$ or laminin322 in SCC has been linked to reduced cell migration and invasion (Moilanen et al., 2017). This migratory and invasive potential is counteracted, at least in invasive melanoma cells, by inhibition of the FAK/PI3K/AKT/mTOR pathway if Collagen XIX binds integrin $\alpha \times \beta 3$. Finally, Collagen VII positively regulates E-cadherin, implying a role for collagen VII in the maintenance of an epithelial, rather than mesenchymal phenotype (Cammareri et al., 2016). Consequently, loss of collagen VII in SCC causes increased TGF $\beta$ signalling.

\section{Interplay between wound healing, inflammation and cancer formation}

During normal wound healing, inflammation occurs transiently and resolves once the wound has healed. However, in some cases the inflammatory response remains activated, leading to chronic inflammation. This is often the case in wounds that have become infected (Eming et al., 2014). There is now a wealth of information linking chronic inflammation to tumour development, and it is known that $15-20 \%$ of all cancer deaths are related to inflammation and/or infection (Arwert et al., 2012; Lund et al., 2016). Inflammation can promote cancer through deregulated or excessive IL-1 $\alpha$, IL-1 $\beta$, TNF $\alpha$, and EGF production, all of which are secreted from chronically activated leukocytes, contributing to tumour progression (Coussens et al., 2013). Chronic inflammation may also promote cancer development by promoting fibrosis (Rosique et al., 2015), since fibrotic tissue is highly conducive to tumour development, in part due to its rigid mechanical properties.

Macrophages also play a key role in both the resolution of wound healing, and the progression from wound healing to tumorigenesis. Whilst macrophages in the early stages of healing control the level of scar formation, and depletion of this population results in improved healing and reduced scar formation, depletion of mid stage macrophages causes impaired tissue maturation and wound closure (Lucas et al., 2010). Furthermore, a deficit in the inability of macrophages to effectively phagocytose neutrophils from the injury site can lead to non-healing wounds (Koh and DiPietro 2011). Since macrophages secrete growth factors and cytokines, they are able to stimulate both growth of healthy epithelial cells required for wound repair, and the growth of cells that have spontaneously acquired oncogenic mutations (Noy and Pollard 2014). Macrophages are the most abundant haematopoietic population in normal skin, are heavily recruited to wound sites and are the most abundant stromal cell population in the tumour microenvironment (Landén et al., 2016; Li et al., 2017b), providing a clear link between their roles in homeostasis, wound healing and cancer. Macrophages, as well as neutrophils, release reactive oxygen species and reactive nitrogen species, which can induce DNA mutations.

In a mouse model of skin wound-induced inflammation and tumour development, a high level of macrophage infiltration 5 days post-injury was found to be predictive of whether a wound would subsequently develop a tumour (Weber et al., 2016). At this time point, there is peak expression of the M2 macrophage marker, arginase-1, which stimulates proliferation of keratinocytes (Sica and Mantovani 2012). One of the main stages where wound healing can develop into tumorigenesis is during the transition from M1 macrophages to M2 macrophages. Typical features of M2-macrophages include the ability to promote angiogenesis and extracellular matrix remodelling, both characteristics that are associated with cancer development (Helm et al., 2014). It is therefore not surprising that tumour-associated macrophages are now thought to have M2-phenotypes (Yang and Zhang 2017). However the exact fate of infiltrating monocytes, and how they contribute to the overall macrophage pool is still unclear (Minutti et al., 2017). Given the crucial roles macrophages play in inflammation and resolution of wound healing, better characterisation of the different subtypes may increase the understanding of how they can be transformed from wound healing cells to tumour promoting cells.

Just as wounding can promote tumour formation in the skin, the presence of existing tumours may affect the healing process of subsequent wounds. For example, wound healing is delayed in mice carrying non-malignant oral squamous cell carcinomas, due to suppressed inflammatory signalling, including a lack of macrophage maturation and disrupted migration of myeloid cells in and out of the wound site (Pyter et al., 2016). 


\section{Conclusions}

The ability of the epidermis to self-renew under steady state conditions and the capacity of the skin to repair following injury have made the epidermis a popular model of adult stem cell behaviour for decades. However recent technological developments have exponentially accelerated our understanding of the epidermis. Novel applications like high-throughput genetic screens and reporter-line based lineage tracing have revealed the complexity of this organ and enabled the identification of multiple populations of stem cells in the epidermis. The addition of single-cell transcriptomic resolution to whole population analysis has allowed a more detailed classification of the heterogeneous and complex epidermal stem cell groups. Therefore, we now have a clearer picture of the dynamic interactions between epidermal cell types, as well as of how they enable the many physiological roles of skin.

Arguably the most important conclusion from recent studies is that the niche plays a central role in determining cell fate. This discovery is especially salient because we now appreciate that the transitions between stem cells and differentiated cells are not unidirectional. Instead, there is emerging evidence of plasticity in various cell populations in the epidermis. This plasticity becomes especially apparent in injury-models, allowing the skin to regenerate and replace damaged tissue from the closest stem cell population, with wound- proximity acting as a manner of master-regulator of cell fate.

This review has discussed how epigenetic, inflammatory, and signalling pathways interact to maintain epidermal homeostasis and mediate wound-healing, and how the pathways that allow for proliferation and regeneration also overlap with carcinogenic risk factors. It is well-known that mammalian capacity for regeneration decreases with age, while the risk of developing cancer increases, and plasticity in the epidermis sheds a novel perspective on the link between these two related processes. As we increase our understanding of epidermal stem cell populations, it may become possible to not only develop a better understanding of the process of ageing, but also shed light on how carcinomas develop, opening new avenues for treatments.

\section{Acknowledgements}

We would like to thank the Wellcome Trust (grant number 108874/Z/15/Z) and King's College London Graduate School for providing funding, and Dr Fay Minty for her constant support. Figures were made using Servier MedicalArt (Dermatology toolkit) in Microsoft Powerpoint with modifications under the terms of the license Creative Commons Attribution 3.0 (https:// creativecommons.org/licenses/by/3.0/).

\section{References}

ADAM RC, YANG H, ROCKOWITZ S, LARSEN SB, NIKOLOVA M, ORISTIAN DS, POLAK L, KADAJA M, ASARE A, ZHEN D et al., (2015). Stem cell plasticity and lineage choice. Nature 521:366-370.

ALIN, ZIRAKB, RODRIGUEZRS, PAULI ML, TRUONG HA, LAIK, AHNR, CORBINK, LOWEMM, SCHARSCHMIDTTC, TARAVATIK, TAN MR, RICARDO-GONZALEZ RR, NOSBAUM A, BERTOLINI M, LIAO W, NESTLE FO, PAUS R, COTSARELI G, ABBAS AK, ROSENBLUM MD (2017). Regulatory T cells in skin facilitate epithelial stem cell differentiation. Cell 169: 1119-1129.

ANTONION, BONNELYKKE-BEHRNDTZML, WARD LC, COLLIN J, CHRISTENSEN IJ, STEINICHE T, SCHMIDT H, FENG Y, MARTIN P (2015). The wound inflammatory response exacerbates growth of pre-neoplastic cells and progression to cancer. EMBO J 34: 2219-2236.
ARAGONAM, DEKONINCK S, RULANDS S, LENGLEZS, MASCRE G, SIMONSBD, BLANPAIN C (2017). Defining stem cell dynamics and migration during wound healing in mouse skin epidermis. Nat Commun 8: 14684.

ARWERT EN, HOSTE E, WATT FM (2012). Epithelial stem cells, wound healing and cancer. Nat Rev Cancer 12: 170-180.

ARWERT EN, LAL R, QUIST S, ROSEWELL I, VAN ROOIJEN N, WATT FM (2010). Tumor formation initiated by nondividing epidermal cells via an inflammatory infiltrate. Proc Natl Acad Sci USA 107: 19903-19908.

AUGUSTIN I (2015). Wht signaling in skin homeostasis and pathology. J Dtsch Dermatolog Ges 13: 302-307.

BLANPAIN C, FUCHS E. (2014). Plasticity of epithelial stem cells in tissue regeneration. Science 344: 1242281-1242281.

BRAUN KM, NIEMANN C, JENSEN UB, SUNDBERG JP, SILVA-VARGAS V, WATT FM (2003). Manipulation of stem cell proliferation and lineage commitment: visualisation of label-retaining cells in wholemounts of mouse epidermis. Development 130: 5241-5255

BROWNS, PINEDACM, XINT, BOUCHERJ, SUOZZIKC, PARKS, MATTE-MARTONE C, GONZALEZ DG, RYTLEWSKI J, BERONJA S, GRECO V (2017). Correction of aberrant growth preserves tissue homeostasis. Nature 548: 334-337.

CAMMARERI P, ROSE AM, VINCENT DF, WANG J, NAGANO A, LIBERTINI S, RIDGWAY RA, ATHINEOS D, COATES PJ, MCHUGH A et al.,2016). Inactivation of TGF $\beta$ receptors in stem cells drives cutaneous squamous cell carcinoma. Nat Commun 7: 1-14.

CANEL M, SERRELS A, FRAME MC, BRUNTON VG (2013). E-cadherin-integrin crosstalk in cancer invasion and metastasis. J Cell Sci 126: 393-401.

CASTELLANA D, PAUS R, PEREZ-MORENO M (2014). Macrophages contribute to the cyclic activation of adult hair follicle stem cells. PLOS Biol 2: e1002002.

CAVAZZA A, MICCIO A, ROMANO O, PETITI L, MALAGOLI TAGLIAZUCCHI G, PEANO C, SEVERGNINI M, RIZZI E, DE BELLIS G, BICCIATO S et al.,2016). Dynamic transcriptional and epigenetic regulation of human epidermal keratinocyte differentiation. Stem Cell Reports 6: 618-632.

CHANG HY, SNEDDON JB, ALIZADEH AA, SOOD R, WEST RB, MONTGOMERY K, CHI J-T, RIJN M, VAN DE BOTSTEIN D, BROWN PO (2004). Gene expression signature of fibroblast serum response predicts human cancer progression: similarities between tumors and wounds. PLOS Biol 2: e7.

CHEN CC, WANG L, PLIKUS MV, JIANG TX, MURRAY PJ, RAMOS R, GUERREROJUAREZ CF, HUGHES MW, LEE OK, SHI S, WIDELITZ RB, LANDER AD, CHUONG CM (2015). Organ-level quorum sensing directs regeneration in hair stem cell populations. Cell 161:277-290.

CHEN H-L, CHIANG P-C, LO C-H, LO Y-H, HSU DK, CHEN H-Y, LIU F-T (2016). Galectin-7 regulates keratinocyte proliferation and differentiation through JNKmiR- 203-p63 signaling. J Invest Dermatol 136: 182-191.

CLAYTON E, DOUPE DP, KELIN AM, WINTON DJ, SIMONS BD, JONES PH (2007) A single type of progenitor cell maintains normal epidermis. Nature 446: 185-189.

COUSSENS LM, ZITVOGE L, PALUCKA AK (2013). Neutralizing tumor-promoting chronic inflammation: a magic bullet? Science 339: 286-291.

DE CRAENE B, DENECKER G, VERMASSEN P, TAMINAU J, MAUCH C, DERORE A, JONKERS J, FUCHS E, BERX G (2014). Epidermal Snail expression drives skin cancer initiation and progression through enhanced cytoprotection, epidermal stem/progenitor cell expansion and enhanced metastatic potential. Cell Death Differ 21: 310-320.

DONATI G, ROGNONIE, HIRATSUKAT, LIAKATH-ALIK, HOSTEE, KARG, KAYIKCI M, RUSSELL R, KRETZSCHMAR K, MULDER KW, TEICHMANN SA, WATT FM (2017). Wounding induces dedifferentiation of epidermal Gata6+ cells and acquisition of stem cell properties. Nat Cell Biol 19:603-613.

DONATI G, WATT FM (2015). Stem cell heterogeneity and plasticity in epithelia. Cell Stem Cell 16: 465-476.

DRISKELLRR, LICHTENBERGERBM, HOSTE E, KRETZSCHMARK, SIMONSBD, CHARALAMBOUS M, FERRON SR, HERAULT Y, PAVLOVIC G, FERGUSONSMITH AC, WATT FM (2013). Distinct fibroblast lineages determine dermal architecture in skin development and repair. Nature 504: 277-281.

DUPERRET EK, DAHAL A, RIDKY TW (2015). Focal-adhesion-independent integrin- $v$ regulation of FAK and c-Myc is necessary for $3 D$ skin formation and tumor invasion. J Cell Sci 128: 3997-4013.

ELBEDIWY A, VINCENT-MISTIAEN ZI, SPENCER-DENE B, STONE RK, BOE- 
ING S, WCULEK SK, CORDERO J, TAN EH, RIDGWAY R, BRUNTON VG et al.,2016). Integrin signalling regulates YAP and TAZ to control skin homeostasis. Development 143: 1674-1687.

EMING SA, KREIG T, DAVIDSON JM (2007) Inflammation in wound repair: molecular and cellular mechanisms. J Invest Dermatol 127: 514-525.

EMING SA, MARTIN P, TOMIC-CANIC M (2014). Wound repair and regeneration: mechanisms, signaling, and translation. Sci Transl Med 6: 265sr6.

GANNON OM, MERIDA DE LONG L. SAUNDERS NA (2016). DUX4 Is derepressed in late differentiating keratinocytes in conjunction with loss of $\mathrm{H} 3 \mathrm{~K} 9 \mathrm{me} 3 \mathrm{epigenetic}$ repression. J Invest Dermatol 136: 1299-302.

GDULAMR, POTERLOWICZK, MARDARYEV AN, SHAROVAA, PENG Y, FESSING MY, BOTCHKAREV VA (2013). Remodeling of three-dimensional organization of the nucleus during terminal keratinocyte differentiation in the epidermis. $J$ Invest Dermatol 133: 2191- 2201.

GE Y, GOMEZ NC, ADAM RC, NIKOLOVA M, YANG H, VERMAA, LU CP-J, POLAK L, YUAN S, ELEMENTO O et al.,2017). Stem cell lineage infidelity drives wound repair and cancer. Cell 169: 636-650.

GENANDER M, COOK PJ, RAMSKOLD D, KEYES BE, MERTZ AF, SANDBERG R, FUCHS E (2014). BMP signaling and its pSMAD1/5 target genes differentially regulate hair follicle stem cell lineages. Cell Stem Cell 15: 619-633.

GOODELL MA, NGUYEN H, SHROYER N (2015) Somatic stem cell heterogeneity: diversity in the blood, skin and intestinal stem cell compartments. Nat Rev Mol Cell Biol 16: 299-309.

GOMEZ C, CHUA W, MIREMADI A, QUIST S, HEADON DJ, WATT FM (2013). The interfollicular epidermis of adult mouse tail comprises two distinct cell lineages that are differentially regulated by Wnt, Edaradd, and Lrig1. Stem Cell Reports 1:19-27.

GREGORIEFF A, LIU Y, INANLOU MR, KHOMCHUK Y, WRANA JL (2015). Yapdependent reprogramming of $\mathrm{Lgr} 5+$ stem cells drives intestinal regeneration and cancer. Nature 526: 715-718.

GUASCH G, SCHOBER M, PASOLLI HA, CONN EB, POLAK L, FUCHS E (2007). Loss of TGF $\beta$ signaling destabilizes homeostasis and promotes squamous cell carcinomas in stratified epithelia. Cancer Cell 12: 313-327.

HELM O, HELD-FEINDT J, SCHAFER H, SEBENS S (2014) M1 and M2: there is no "good" and "bad"-how macrophages promote malignancy-associated features in tumorigenesis. Oncoimmunol 3: e946818.

HONG AW, MENG Z, GUAN K-L (2016). The Hippo pathway in intestinal regeneration and disease. Nat Rev Gastroenterol Hepatol 13:324-337.

HUANG R-L, TEO Z, CHONG HC, ZHU P, TAN MJ, TAN CK, LAM CRI, SNG MK, LEONG DTW, TAN SM et al.,2011). ANGPTL4 modulates vascular junction integrity by integrin signaling and disruption of intercellular VE-cadherin and claudin-5 clusters. Blood 118: 3990-4002.

IZUKA H (1994). Epidermal turnover time. J Dermatol Sci 8: 215-217.

JONES PH, SIMONS BD, WATT FM (2007) Sic transit gloria: farewell to the epidermal transit amplifying cell? Cell Stem Cell 1: 371-381.

JOOST S, ZEISEL A, JACOB T, SUN X, LA MANNO G, LONNNERBERG P, LINNARSSON S, KASPER M (2016). Single-cell transcriptomics reveals that differentiation and spatial signatures shape epidermal and hair follicle heterogeneity. Cell Syst 3: 221-237.

JUNG J-W, OVERGAARD NH, BURKE MT, ISBEL N, FRAZER IH, SIMPSON F, WELLS JW (2016). Does the nature of residual immune function explain the differential risk of non- melanoma skin cancer development in immunosuppressed organ transplant recipients? Int J Cancer 138: 281-292.

KADAJA M, KEYES BE, LIN M, PASOLLI HA, GENANDER M, POLAK L, STOKES N, ZHENG D, FUCHS E (2014). SOX9: a stem cell transcriptional regulator of secreted niche signaling factors. Genes Dev 28: 328-341.

KARASEK J, SMETANA K, HRDLICKA A, DUBININ I, HORNAK O, OHERLERT W (1972). Nuclear and nucleolar ultrastructure during the late stages of normal human keratinocyte maturation. Br J Dermatol 86: 601-607.

EL KHARBILI M, ROBERT C, WITKOWSKI T, DANTY-BERGER E, BARBOLLATBOUTRAND L, MASSE I, GADOT N, DELAFOUCHARDIEREA, MCDONALD PC, DEDHAR $S$ et al.,2017). Tetraspanin 8 is a novel regulator of ILK-driven $\beta 1$ integrin adhesion and signaling in invasive melanoma cells. Oncotarget 8: 17140-17155.

$\mathrm{KOH}$ TJ, DIPIETRO LA (2011). Inflammation and wound healing: the role of the macrophage. Expert Rev Mol Med 13: e23.

KRETZSCHMAR K, WEBER C, DRISKELL RR, CALONJE E, WATT FM (2016).
Compartmentalized epidermal activation of $\beta$-catenin differentially affects lineage reprogramming and underlies tumor heterogeneity. Cell Rep 14:269-281.

LANDEN NX, LI D, STAHLE M (2016). Transition from inflammation to proliferation: a critical step during wound healing. Cell Mol Life Sci 73: 3861-3885.

LANE SW, WILLIAMS D, WATT FM (2014). Modulating the stem cell niche for tissue regeneration. Nature Biotech 32: 795-803.

LATIL M, NASSAR D, BECK B, BOUMAHDI S, WANG L, BRISEBARRE A, DUBOIS C, NKUSI E, LENGLEZ S, CHECINSKAA et al.,2017). Cell-type-specific chromatin states differentially prime squamous cell carcinoma tumor-initiating cells for epithelial to mesenchymal transition. Cell Stem Cell 20: 191-204.

LAY K, KUME T, FUCHS E (2016). FOXC1 maintains the hair follicle stem cell niche and governs stem cell quiescence to preserve long-term tissue-regenerating potential. Proc Natl Acad Sci USA 113: E1506-1515.

LI G, YE Z, SHI C, SUN L, HAN M, ZHUANG Y, XU T, ZHAO S, WU X (2017a). The histone methyltransferase Ash1l is required for epidermal homeostasis in mice. Sci Rep 7: 45401.

LI H, CHANG L, DU WW, GUPTA S, KHORSHIDI A, SEFTON M, YANG BB (2014). Anti-microRNA-378a enhances wound healing process by upregulating integrin beta-3 and vimentin. Mol Ther 22: 1839-1850.

LI R, HEBERT JD, LEE TA, XING H, BOUSSOMMIER-CALLEJA A, HYNES RO, LAUFFENBURGER DA, KAMM RD (2017b). Macrophage-secreted TNF $\alpha$ and TGF $\beta 1$ influence migration speed and persistence of cancer cells in 3D tissue culture via independent pathways. Cancer Res 77: 279-290.

LIM X, TAN SH, KOH WLC, CHAU RMW, YAN KS, KUO CJ, VAN AMERONGEN R, KLEIN AM, NUSSE R (2013). Interfollicular epidermal stem cells self-renew via autocrine Wnt signaling. Science 342: 1226-1230.

LOFFEK S, HURSKAINEN T, JACKOW J, SIGLOCH FC, SCHILLING O, TASANEN K, BRUCKNER-TUDERMAN L, FRANZKE C-W (2014). Transmembrane collagen XVII modulates integrin dependent keratinocyte migration via PI3K/Rac1 signaling. PLoS One 9: e87263.

LONGMATE WM, MONICHAN R, CHU M-L, TSUDA T, MAHONEY MG, DIPERSIO CM (2014). Reduced Fibulin-2 contributes to loss of basement membrane integrity and skin blistering in mice lacking integrin $\alpha 3 \beta 1$ in the epidermis. $J$ Invest Dermatol 134: 1609-1617.

LUCAS T, WAISMAN A, RANJAN R, ROES J, KRIEG T, MUULER W, ROERS A, EMING SA (2010). Differential roles of macrophages in diverse phases of skin repair. J Immunol 184: 3964-3977.

LUNDAW, MEDLERTR, LEACHMANSA, COUSSENS LM (2016). Lymphatic vessels, inflammation, and immunity in skin cancer. Cancer Discov 6: 22-35.

LUO C, LIM J-H, LEE Y, GRANTER SR, THOMAS A, VAZQUEZ F, WIDLUND HR, PUIGSERVER P (2016). A PGC1 $\alpha$-mediated transcriptional axis suppresses melanoma metastasis. Nature 537: 422-426.

LYNCH MD, WATT FM (2018). Fibroblast heterogeneity: implications for human disease. J Clin Invest. 128: 26-35.

MACLEOD AS, HEMMERS S, GARIJO O, CHABOD M, MOWEN K, WITHERDEN DA, HAVRAN WL (2013). Dendritic epidermal T cells regulate skin antimicrobial barrier function. $J$ Clin Invest 123: 4364-4374.

MARTINEZ FO, GORDON S (2014). The M1 and M2 paradigm of macrophage activation: time for reassessment. F1000Prime Rep 6: 13.

MARTINS VL, CALEY MP, MOORE K, SZENTPETERY Z, MARSH ST, MURRELL DF, KIM MH, AVARI M, MCGRATH JA, CERIO R et al.,2016). Suppression of TGF $\beta$ and angiogenesis by Type VII collagen in cutaneous SCC. J Natl. Cancer Inst 108: djv293.

MASCRE G, DEKONINCKS, DROGATB, YOUSSEF KK, BROHEE S, SOTIROPOULOU PA, SIMONS BD, BLANPAIN C (2012). Distinct contribution of stem and progenitor cells to epidermal maintenance. Nature 489: 257-262.

MINUTTICM, KNIPPERJA, ALLEN JE, ZAISS DMW (2017). Tissue-specific contribution of macrophages to wound healing. Sem Cell Dev Biol 61: 3-11.

MOILANEN JM, LOFFEKS, KOKKONEN N, SALO S, VAYRYNEN JP, HURSKAINEN T, MANNINEN A, RIIHILA P, HELJASVAARA R, FRANZKE C-W et al.,2017). Significant role of collagen XVII and integrin $\beta 4$ in migration and invasion of the less aggressive squamous cell carcinoma cells. Sci Rep 7: 45057.

NA J, LEE K, NA W, SHIN J-Y, LEE M-J, YUNE TY, LEE HK, JUNG H-S, KIM WS, JU B-G (2016). Histone H3K27 demethylase JMJD3 in cooperation with NF-KB regulates keratinocyte wound healing. J Invest Dermatol 136: 847-858. 
NOY R, POLLAARD JW (2014). Tumor-associated macrophages: from mechanisms to therapy. Immunity 41: 49-61.

OKUYAMA R, TAGAMI H, AIBA S (2008). Notch signaling: Its role in epidermal homeostasis and in the pathogenesis of skin diseases. J Dermatol Sci 49, 187-194.

OSHIMORI N, ORISTIAN D, FUCHS E (2015). TGF- $\beta$ promotes heterogeneity and drug resistance in squamous cell carcinoma. Cell 160: 963-976.

OWENS DM, WATT FM (2003). Contribution of stem cells and differentiated cells to epidermal tumours. Nat Rev Cancer 3: 444-451.

PAGE ME, LOMBARD P, NG F, GOTTGENS B, JENSEN KB (2013). The epidermis comprises autonomous compartments maintained by distinct stem cell populations. Cell Stem Cell 13: 471-482.

PANTAZI E, GEMENETZIDIS E, THE M-T, REDDY SV, WARNES G, EVAGORA C, TRIGIANTE G, PHILPOTT MP (2017). GLI2 Is a regulator of $\beta$-catenin and is associated with loss of E-cadherin, cell invasiveness, and long-term epidermal regeneration. J Invest Dermatol 137: 1719-1730.

PARK S, GRECO V, COCKBURN K (2016). Live imaging of stem cells: Answering old questions and raising new ones. Curr Opin Cell Biol 43: 30-37.

PYTER LM, HUSAINY, CALERO H, MCKIM DB, LIN H-Y, GODBOUT JP, SHERIDAN JF, ENGELAND CG, MARUCHAPT (2016). Tumors alter inflammation and impair dermal wound healing in female mice. PLoS One 11: e0161537.

RAJAGOPAL J, STANGER BZ (2016). Plasticity in the adult: how should the Waddington diagram be applied to regenerating tissues? Dev Cell 36: 133-137.

REINKE JM, SORG H (2012). Wound repair and regeneration. Eur. Surg. Res. 49, 35-43.

RICHARDSON R, METZGER M, KNYPHAUSEN P, RAMEZANI T, SLANCHEV K, KRAUS C, SCHMELZER E, HAMMERSCHMIDT M (2016). Re-epithelialization of cutaneous wounds in adult zebrafish combines mechanisms of wound closure in embryonic and adult mammals. Development 143: 2077-2088.

RINALDI L, DATTA D, SERRAT J, MOREY L, SOLANAS G, AVGUSTINOVA A, BLANCO E, PONS JI, MATALLANAS D, VON KRIEGSHEIM A et al.,2016). Dn$\mathrm{mt} 3 \mathrm{a}$ and Dnmt3b associate with enhancers to regulate human epidermal stem cell homeostasis. Cell Stem Cell 19: 491-501.

ROGNONIE, GOMEZC, PISCOAO, RAWLINSEL, SIMONSBD, WATTFM, DRISKELL RR (2016). Inhibition of $\beta$-catenin signalling in dermal fibroblasts enhances hair follicle regeneration during wound healing. Development 143: 2522-2535.

ROGNONIE, WIDMAIERM, JAKOBSONM, RUPPERTR, USSARS, KATSOOUGKRI D, BOTTCHER RT, LAI-CHEONG JE, RIDKIN DB, MCGRATH JA et al.,2014). Kindlin-1 controls Wnt and TGF- $\beta$ availability to regulate cutaneous stem cell proliferation. Nat Med 20: 350-359.

ROMPOLAS P, MESA KR, GRECO V (2013). Spatial organization within a niche as a determinant of stem-cell fate. Nature 502: 513-518.

ROSIQUE RG, ROSIQUE MJ, FARINA JUNIOR JA (2015). Curbing inflammation in skin wound healing: A review. Int J Inflam 2015: 316235

SADA A, JACOB F, LEUNG E, WANG S, WHITE BS, SHALLOWAY D, TUMBAR T (2016). Defining the cellular lineage hierarchy in the interfollicular epidermis of adult skin. Nat Cell Biol 18: 619-631.

SCHEPELER T, PAGE ME, JENSEN KB (2014). Heterogeneity and plasticity of epidermal stem cells. Development 141: 2559-2567.
SCHMIDT B, HORSLEY V (2012). Unravelling hair follicle-adipocyte communication. Exp Dermatol 21: 827-830.

SCHMUTHM, MOOSBRUGGER-MARTINZV, BLUNDERS, DUBRAC S (2014). Role of PPAR, LXR, and PXR in epidermal homeostasis and inflammation. Biochim Biophys Acta - Mol Cell Biol Lipids 1841: 463-473.

SICAA, MANTOVANIA(2012). Macrophage plasticity and polarization: in vivo veritas. J Clin Invest 122: 787-795.

SRIVASTAVA J, RHO O, YOUSSEF RM, DIGIOVANNI J (2016). Twist1 regulates keratinocyte proliferation and skin tumor promotion. Mol Carcinog 55: 941-952.

STRBO N, YIN N, STOJADINOVIC O (2014). Innate and adaptive immune responses in wound epithelialization. Adv Wound Care 3: 492-501.

SUN B, SIPRASHVILI Z, KHAVARI P (2014) Advances in skin grafting and treatment of cutaneous wounds. Science 346: 941-945

TAN DWM, JENSEN KB, TROTTER MWB, CONNELLY JT, BROAD S, WATT FM (2013). Single-cell gene expression profiling reveals functional heterogeneity of undifferentiated human epidermal cells. Development 140: 1433-1444.

TANIGUCHI K, WU L-W, GRIVENNIKOV SI, DE JONG PR, LIAN I, YU F-X, WANG $\mathrm{K}$, HO SB, BOLAND BS, CHANG JT et al.,2015). A gp130-Src-YAP module links inflammation to epithelial regeneration. Nature 519: 57-62.

TASANENK, TUNGGALL, CHOMETON G, BRUCKNER-TUDERMANL, AUMAILLEY $M$ (2004). Keratinocytes from patients lacking collagen XVII display a migratory phenotype. Am J Pathol 164: 2027-2038.

TI D, LI M, FU X, HAN W (2014). Causes and consequences of epigenetic regulation in wound healing. Wound Repair Regen 22: 305-312.

VITICCHIE G, LENA AM, CIANFARANI F, ODORISIO T, ANNICCHIARICO-PETRUZZELLI M, MELINO G, CANDI E (2012). MicroRNA-203 contributes to skin re-epithelialization. Cell Death Dis 3: e435.

WATT FM (2014). Mammalian skin cell biology: at the interface between laboratory and clinic. Science 346: 937-940.

WEBER C, TELERMAN SB, REIMERAS, SEQUEIRAI, LIAKATH-ALIK, ARWERTEN, WATT FM (2016). Macrophage infiltration and alternative activation during wound healing promote MEK1-induced skin carcinogenesis. Cancer Res 76: 805-817.

XIANG Y, ZHU Z, HAN G, LIN H, XU L, CHEN CD (2007). JMJD3 is a histone H3K27 demethylase. Cell Res 17: 850-857.

XUEM, JACKSONCJ (2015). Extracellular matrix reorganization during wound healing and its impact on abnormal scarring. Adv Wound Care 4: 119-136.

YANG H, SCHRAMEK D, ADAM RC, KEYES BE, WANG P, ZHENG D, FUCHS $E$ (2015). ETS family transcriptional regulators drive chromatin dynamics and malignancy in squamous cell carcinomas. eLife 4: e10870.

YANG H, ADAM RC, GE Y, HUA ZL, FUCHS E (2017). Epithelial-mesenchymal micro-niches govern stem cell lineage choices. Cell 169: 483-489.

YANG L, ZHANG L (2017) Tumor-associated macrophages: from basic research to clinical application. J Hematol Oncol 10: 58.

YIR, POY MN, STOFFEL M, FUCHS E (2008). A skin microRNA promotes differentiation by repressing "stemness." Nature 452: 225-229.

ZHANG X, WU J, LUO S, LECHLERT, ZHANG JY (2016). FRA1 promotes squamous cell carcinoma growth and metastasis through distinct AKT and c-Jun dependent mechanisms. Oncotarget 7: 34371-34383. 


\section{Further Related Reading, published previously in the Int. J. Dev. Biol.}

Epiblast-derived stem cells in embryonic and adult tissues

Maria P. De-Miguel, Francisco Arnalich-Montiel, Pilar Lopez-Iglesias, Alejandro Blazquez-Martinez and Manuel Nistal

Int. J. Dev. Biol. (2009) 53: 1529-1540

https://doi.org/10.1387/ijdb.072413md

Reptile scale paradigm: Evo-Devo, pattern formation and regeneration

Cheng Chang, Ping Wu, Ruth E. Baker, Philip K. Maini, Lorenzo Alibardi and Cheng-Ming Chuong

Int. J. Dev. Biol. (2009) 53: 813-826

https://doi.org/10.1387/ijdb.072556cc

Analyses of regenerative wave patterns in adult hair follicle populations reveal macro-environmental regulation of stem cell activity Maksim V. Plikus, Randall B. Widelitz, Rob Maxson and Cheng-Ming Chuong

Int. J. Dev. Biol. (2009) 53: 857-868

https://doi.org/10.1387/ijdb.072564mp

Adult epidermal keratinocytes are endowed with pilosebaceous forming abilities C Ferraris, B A Bernard and D Dhouailly

Int. J. Dev. Biol. (1997) 41: 491-498

http://www.intjdevbiol.com/web/paper/9240566

Appearance of tenascin in healing skin of the mouse: possible involvement in seaming of wounded tissues

R Murakami, I Yamaoka and T Sakakura

Int. J. Dev. Biol. (1989) 33: 439-444

http://www.intjdevbiol.com/web/paper/2484288

Appearance of tenascin in healing skin of the mouse: possible involvement in seaming of wounded tissues

R Murakami, I Yamaoka and T Sakakura

Int. J. Dev. Biol. (1989) 33: 439-444

http://www.intjdevbiol.com/web/paper/2484288

5 yr ISI Impact Factor $(2016)=2.421$
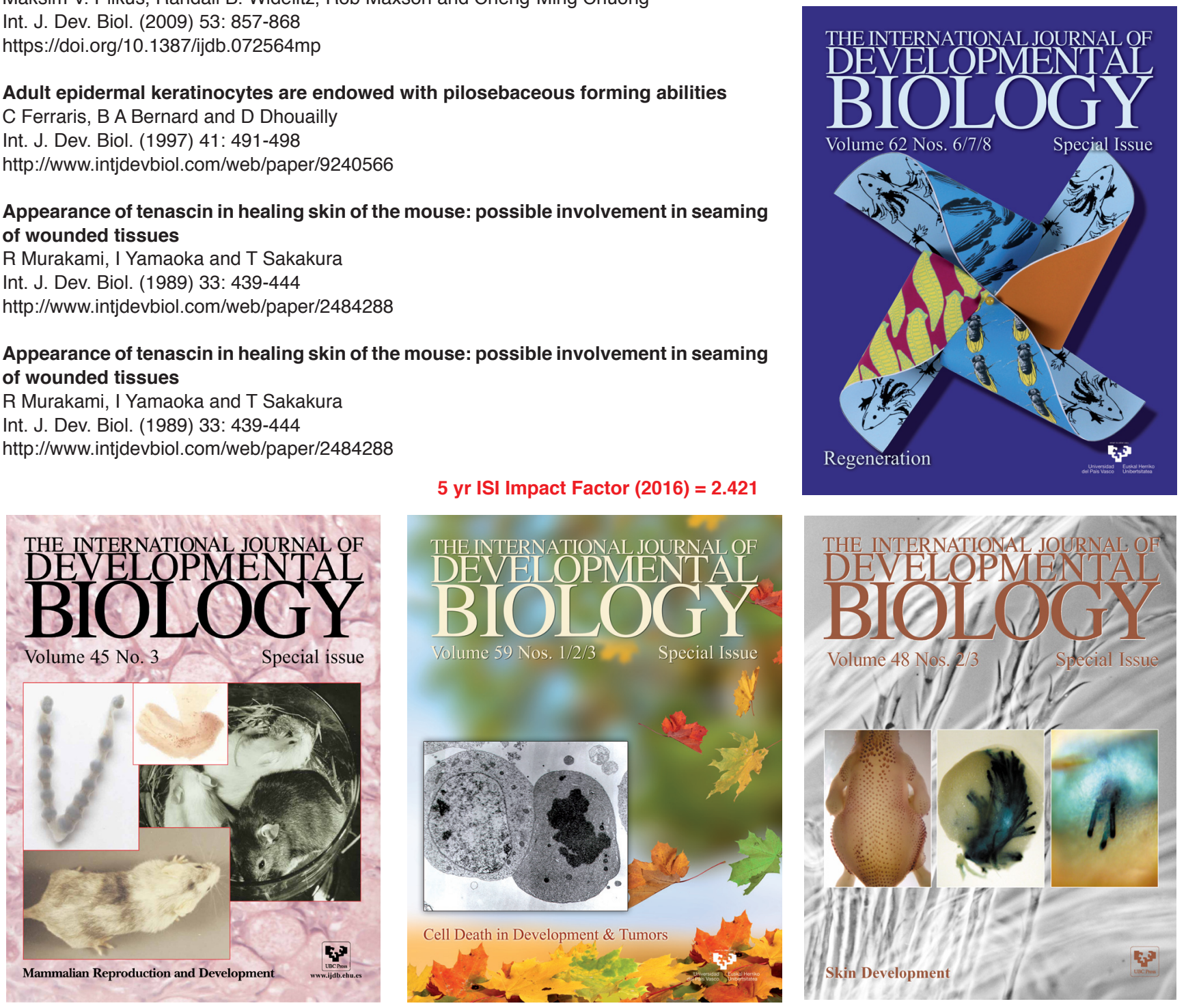